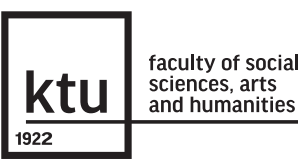

SAL 38/2021

Research Journal Studies about Languages pp. $43-60$

ISSN 1648-2824 (print)

ISSN 2029-7203 (online)

DOI 10.5755/j01.sal.1.38.26581
LINGUISTICS / KALBOTYRA

Emotional State GEMÜTLICHKEIT in Cross-cultural Perspective: Corpus-based Approach

Received 06/2020

Accepted 02/2021

rrossef http://dx.doi.org/10.5755/j01.sal.1.38.26581

HOW TO CITE: Mizin, K., \& Petrov, O. (2021). Emotional state GEMÜTLICHKEIT in cross-cultural perspective: Corpus-based approach. Studies about Languages / Kalbu studijos 38, 43-60. http://doi.org/10.5755/j01.sal.1.38.26581

\title{
Emotional State GEMÜTLICHKEIT in Cross-cultural Perspective: Corpus-based Approach
}

\author{
GEMÜTLICHKEIT emocinė būsena tarpkultūriniame kontekste: \\ tekstynu grịstas tyrimas
}

\begin{abstract}
KOSTIANTYN MIZIN, Pereiaslav-Khmelnytskyi Hryhorii Skovoroda State Pedagogical University, Ukraine
OLEKSANDR PETROV, Vinnytsia Mykhailo Kotsiubinsky State Pedagogical University, Ukraine
\end{abstract}

\begin{abstract}
The article is devoted to the cross-cultural study of the concept GEMÜTLICHKEIT representing Abstract ethnospecific emotional state relevant for the German-speaking community. To achieve the aim the language specific of the name of this concept - lexeme Gemütlichkeit - was revealed with the help of etymological, definitional, and contextual analysis, as well as the search for the interlingual equivalents, the usage of cross-cultural data and the data of representational language corpus. It has been proved that the concept GEMÜTLICHKEIT together with the concepts SICHERHEIT, ZUVERLÄSSIGKEIT and GEBORGENHEIT forms a unique "safety-cosiness quartet" of the German-speaking communities value system, i.e., the fragment of the world picture which together with the concept ORDNUNG is opposed to the existential fear ANGST. A semantic profile of the word query Gemütlichkeit was built on the basis of the language corpus data. The profile "peaks" are the key features of the concept GEMÜTLICHKEIT. These features form the basis of the relevant definition of the lexeme Gemütlichkeit. The development of the definition was aimed not only at closing the gap in reference literature that needs a clear and complete definition of the concept GEMÜTLICHKEIT, but also at forming an adequate idea of this emotional state in the minds of the representatives of non-German speaking communities.
\end{abstract}

KEYWORDS: emotional state, emotional concept, language corpus, corpus-based method, semantic profile.

"Es geht nichts über die Gemütlichkeit!: Wenn ein Ausländer diese Redensart hört, ist es ihm fast unmöglich, sich das vorzustellen, was wir Deutschen darunter verstehen" (Krüger-Lorenzen, 1972, p. 685).

[Es geht nichts über die Gemütlichkeit!: When a foreigner hears this phrase he can hardly realize what we - Germans - mean by it.] 
Cognitive linguistics that appeared in the second half of the $20^{\text {th }} \mathrm{c}$. has become an "umbrella" embracing several research areas aimed at the study of human cognition (psychology, neuroscience, linguistics, artificial intelligence science, etc.). All the disciplines that have appeared within the cognitive science have a distinct cross-cultural nature and, correspondingly, cross-cultural methodology. The latter has opened new possibilities for a more scientifically objective research of mental (cognitive) processes and structures of human consciousness. It refers among other things to the problem of close correlation of these structures and processes with language and speech, which issue is the focus of interest first and foremost for the representatives of cognitive linguistics.

Cross-cultural character of cognitive linguistics is especially obvious in its close connection with psychological sciences, in particular cognitive psychology and Gestalt psychology. As a result of methodological symbiosis of linguistics and psychology, adherents of cognitive linguistics started active research of the problem of human emotions categorization and conceptualization (Kövecses, 1990; Wierzbicka, 1999). At present, the study of these issues is no less actively conducted within such branches of cognitive linguistics as cultural linguistics and linguoculturology (Dewaele, 2015; Mizin \& Letiucha, 2019; Mizin et al., 2019; Mizin \& Ovsiienko, 2020; Panasenko, 2012; Wilson \& Lewandowska-Tomaszczyk, 2017). These disciplines differ in their analytical toolkit, but they actually solve the same problems (Mizin \& Korostenski, 2019).

Much attention is paid by researchers to the issue of the effect sociohistorical, sociocultural and ethnocultural factors have on the emotions categorization and conceptualization. The problem preserves its topicality as it directly correlates with the burning issues of the day: globalization, cross-cultural communication, etc. Especially promising are the studies devoted to the analysis of ethnospecific emotions (emotional states, feelings), since the results and conclusions of such studies can give scientifically reliable data about the specificity of the worldview and world-conception of a definite linguistic community (Mizin \& Letiucha, 2019). Methodologically these studies are based on the observation of psychologists that in the process of socialization even basic and universal emotions obtain ethnocultural shades of meaning that influence their expression and perception by this or that linguistic ethnic group (see, e.g., Elfenbein \& Ambady, 2002; Friedlmeier et al., 2011; Röttger-Rössler \& Markowitsch, 2009). This conclusion has been verified and to a certain extent confirmed by numerous sociological and culture studies (see, e.g., Briggs, 1970; Reddy, 2012; Robinson \& Altarriba, 2015).

A peculiar feeling of cosiness designated by the lexeme Gemütlichkeit is one of the ethnospecific emotional states that has been particularly relevant to the German-speaking cultural community for a long time. The relevance of the concept GEMÜTLICHKEIT can be proved by the fact that on 2 August 2015 Oxford electronic dictionary Lexico called the noun Gemütlichkeit the word of the day (Lexico, 2020). Here only two meanings of the word are reflected: (a) 'geniality' and (b) 'friendliness', which is not exactly correct as the lexeme Gemütlichkeit denotes a much more complex ethnocultural notion and the present research aims to reveal its semantic complexity. Therefore, the purpose of the given article is (a) to define the semantic content (etymological and conceptual features) of the lexeme Gemütlichkeit by means of finding corresponding cross-cultural elements and using cross-cultural data, (b) to reveal relevant senses of the lexeme and to develop a semantic profile of the latter using the language corpus data, and (c) to give a relevant definition of the analysed lexeme on the basis of its semantic profile. Specificity of ethnocultural marked concepts is most clearly revealed in cross-cultural comparison; therefore, the analysis of the lexeme Gemütlichkeit is done not only on the material of the German language, but also involves partial usage of the data from several Romance, Germanic, and Slavic languages.

Theoretical Background of the Research
Being involved in the processes of objective reality categorization and conceptualization, emotions possess both cognitive and affective features, which fact explains their undeniable connection with culture (for more details see Dewaele, 2015). It stands to reason that the most noticeable cultural markedness can be traced in the peculiar emotions showing close connection with the linguoculture they are related to. These emo-

tions serve as a starting point for the study of the so-called emotional concepts in cognitive linguistics, the most well-known of which are culture oriented theories of Wierzbicka (1999) and Kövecses (1990). Wierzbicka's (1999) Natural Semantic Metalanguage (NSM) describes emotions, in particular the German emotional concept ANGST, with the help of "universal semantic primitives". NSM is a propositional approach that aims to formulate the con- 
ditions of a certain psychological state by means of propositions. Wierzbicka (1999) suggests that the concept ANGST is unique and differs from similar concepts in other languages due to psychological, philosophical and theological traditions. The specific character of this emotion is characterized by an indeterminate expectation of "bad things". At the same time this emotion is irrational since it is beyond a person's comprehension why one feels ANGST. According to Wierzbicka's approach, the researcher's intuition is crucial for a pragmatic analysis of cultural prototypical situations. As opposed to Wierzbicka's NSM conception, Kövecses' lexical approach introduces a more empirical element by means of the analysis of conventionalized expressions. The data used for studies in the lexical approach are either elicited or extracted from lexicographical sources. As long as language and its lexicon in particular are the reflection of human conceptual system, it is possible to reveal the complex structure of emotional concepts with the help of the analysis of conventionalized lingual expressions - metaphors, metonymies, idioms, clichés, proverbs, collocations, etc. (Kövecses, 1990).

Wierzbicka's and Kövecses' pioneering works have stimulated active research into emotional concepts in the field of cognitive linguistics as well as cultural linguistics (in the post-Soviet countries - linguoculturology), where emotions are viewed as cultural categories or linguocultural concepts. However, regardless of scholarly traditions and approaches, the topical methodological issue concerning the reduction of introspection influence in linguocultural studies of the kind still has not been solved. It is one of the reasons why in modern studies focusing on the analysis of emotional concepts, a corpus-based approach is gaining popularity. The latter can enhance the scientific credibility of the given studies by providing empirical toolkit. Here one should first of all mention a promising corpus-based methodology suggested by Stefanowitsch (2005) for the study of cognitive metaphors representing emotional concepts. This method, known as metaphorical pattern analysis (MPA), lies in choosing a lexical item referring to the target domain under investigation, extracting a random sample of its occurrences in the corpus, identifying all metaphorical expressions that the search word is a part of, and grouping them according to general mappings. In this context Stefanowitsch claims that almost all metaphors described in introspective studies can be identified with the help of corpus analysis.

It was the empirical potential of corpus linguistics that stimulated us to develop and present in this research our own corpus-based methodology aimed at bringing out the specificity of the emotional concept GEMÜTLICHKEIT relevant for the German linguoculture. However, the focus of research here is not on the study of cognitive metaphors representing the concept, but on revealing those of its semantic facets, which make its understanding possible for the representatives of other linguocultures since GEMÜTLICHKEIT is a very complex mental (cognitive) construct that forms a part of mental and material world of the German-speaking communities. That is why numerous psychological, sociological and cultural studies are devoted at present to the analysis of the emotional state GEMÜTLICHKEIT.

Thus, in psychology, this state of the peace of mind is studied together with the therapeutic practices as it constitutes a whole set of emotions, feelings, desires and moods. Psychologists define it as (a) the quality of the good-natured, sanguine, easy-going disposition; (b) good nature; (c) kindliness; (d) geniality; (e) pleasantness; (f) cordiality; (g) sentiment, tenderness of feeling; (h) freedom from pecuniary cares; (i) comfortableness (Fransella, 1995).

In their turn sociologists and culture experts have disclosed sociohistorical and sociocultural preconditions for the appearance of the concept GEMÜTLICHKEIT stressing that the latter emerged on the German-speaking territories within a social middle class - burghers. The notion acquired particular meaning in the Biedermeier epoch as "the era of privacy" (Döcker, 1994, p. 10), when burghers found a kind of protection from constant political, social and economic changes in returning to their families, close people and homes. It was at that particular period that the concept GEMÜTLICHKEIT started to be embodied in corresponding forms (dwellings style, social clubs design etc.) and social practices (various social clubs, common pastimes, tea ceremonies, community meals etc.) (Schmidt-Lauber, 2004), gradually spreading within the European German-speaking area (it concerns first of all the territories of modern Germany, Austria and Switzerland).

In spite of the standing three-century long relevance, the concept GEMÜTLICHKEIT has not been given due attention to by the linguists regardless of the fact that there is no complete definition of the lexeme Gemütlichkeit in contemporary dictionaries (cf. "1. a) [the feeling of] comfortable atmosphere; b) casual sociability; informality; c) calmness, leisureliness; 2 . something that has an effect of comfort' (Duden, 2020)). The attempts to reveal 
the essence of this notion have been made only in some linguistic studies, mostly in cross-cultural ones (see, e.g., Medvedeva et al., 2011; Popova et al., 2009; Zaliznyak et al., 2005). Rather notable is also the absence of works devoted to the linguistic analysis of the concept GEMÜTLICHKEIT with the results and conclusions being reinforced by means of corpus-based methodology.

Methods and

To achieve the aim of the research, corpus-based methodology is approbated, which involves the usage of five research procedures. It is connected with the fact that cultural linguistic studies are often criticized for their analytical toolkit lacking scientific credibility, which demands constant improvement of their scientific methodology. A considerable Data reinforcement of the results and conclusions can be achieved with the help of data and digital opportunities offered by corpus linguistics (Kamandulytè-Merfeldienè \& Balčiūnienè, 2016; McEnery \& Wilson, 2001; Oster, 2012).

Procedures 1-3: (a) revealing the etymology of the lexeme Gemütlichkeit, (b) defining its content (semantic shades), and (c) comparing the lexeme definitions in German and English against the background of partial cross-cultural counterparts in several Romance, Germanic, and Slavic languages. Aim: (a) to reveal etymological features of the word Gemütlichkeit, which underlie its figurative-motivational basis (inner form), and (b) by means of interlingual analysis to define those semantic shades of the latter that are not fixed in lexicographical sources and are not offset by the semantics of partial cross-cultural counterparts.

Procedure 4: establishing relevant senses of the concept GEMÜTLICHKEIT by means of analysis of concordance fragments (concordance lines), built automatically on the basis of the corresponding word query. For this purpose, the representational German language corpus Leipzig Corpora Collection (LCC, 2020) was used. Aim: to reveal the current picture of the concept GEMÜTLICHKEIT existing in the minds of the representatives of German-speaking cultural space.

Procedure 5: developing semantic profile of the word query Gemütlichkeit. A semantic profile, in our understanding, is a result of analysis of the data that concerns the most frequent 1) co-occurrent similar forms, (2) co-occurrents, (3) left and right collocates of this word, that is why it is a schematic representation of the word's condensed semantic features. Accordingly, it should not be confused with Stubbs' notion of "a semantic profile" (Stubbs, 1995). Here the term semantic "is derived from the intuition that words, which can be seen in the context of a given word, contribute to its meaning" (Bruza et al., 2009, p. 71). Aim: to define those basic conceptual features that form a contemporary idea of the analysed emotional state in the minds of the German language native speakers. The semantic profile makes it possible to work out a clear and at the same time complete contemporary definition of the lexeme Gemütlichkeit. The latter can help create a more or less complete picture of the concept GEMÜTLICHKEIT in the minds of representatives of non-German speaking communities.

\section{Results and \\ Discussion}

Language specificity of the lexeme Gemütlichkeit: etymological, definitional, and cross-cultural analysis

Linguospecificity of a language unit manifests itself first of all in its non-translatability, i.e. impossibility to find a full translation equivalent in other world languages. It goes without saying that not all languages are meant here as it is next to impossible to put into practice, but only those of a definite language area - (a) a separate language group, (b) some language groups within a common language family, (c) certain language groups within different language families. That is why when we speak about the German language it is logical to look for the equivalents in other Germanic languages, first of all English as it is not only closely related to German but is also one of the most widely spread languages in the world. Moreover, it has become a dominant language of science which caused the active process of borrowing English terminology into other languages. The opposite process becomes prominent on this background, namely borrowing or, to be more exact, loan-translating of German lexical units with distinct linguocultural colouring into the English language. The latter belong to such branches as psychology, anthropology, sociology and culture studies: e.g., Schadenfreude, Angst, Sehnsucht, Weltschmerz, Fremdschämen, Vergangenheitsbewältigung.

The lexeme Gemütlichkeit often functions in the English language as translation-loan since it denotes the notion that is rather obscure to the Anglo-Saxons. As a rule, English-speaking researchers point out the polysemy of the 
lexeme that renders the semantics of geniality, comfort and warmth (Winawer \& Wetzel, 2005). A typical picture of understanding the German notion "Gemütlichkeit" is reflected in a condensed way in the encyclopaedia of the anthropologist J. Cole "Ethnic Groups of Europa" (2011): "Gemütlichkeit is usually associated with the middle class and evokes candlelight, soft plush pillows, and naive paintings of countryside and animals; whatever the social setting, Gemütlichkeit always connotes safety and security, and evokes the qualities conveyed by the English term "cosiness'" (p. 177). Firstly, such understanding is incomplete and inaccurate (the contemporary definition of the concept GEMÜTLICHKEIT, based on the results of our analysis, no longer points to the direct connection of this concept with the middle class). Secondly, the noun cosiness, as well as the adjective cosy, gives just a fragmentary reflection of the semantics of the German words Gemütlichkeit and gemütlich. It must be noted though that scholars are not unanimous on this point: some of them refuse to recognize the synonymy of cosiness and German Gemütlichkeit (see, e.g., Wiking, 2016); others, on the contrary, claim that cosiness is a complete equivalent of the latter (see, e.g., Jenkins, 2014).

As a matter of fact, semantic differences between the English cosiness and German Gemütlichkeit are of a deeper nature as they can be traced even in the etymology of these words. Thus, according to one of the etymological versions, the English cosiness / cosy comes from a Gaulish word cosag, denoting a small pit or burrow, where one could hide from the enemies, rain, wind, cold etc. (Smith, 2015). In contrast to this, gemütlich is derived from a late Middle High German word gemüetlich, which combines the meanings of two words - a Middle High German gemüete in the meaning 'something that touches the soul (the core)' and an Old High German gimuati 'common way of world comprehension, nice, pleasant' (DH, 2001, p. 265). Unlike the lexeme cosiness, the basic etymological motives of which are "safety" and "cosiness", the word Gemütlichkeit from the very beginning denoted a more complex fragment of a human emotional state formed as a result of the amalgam of several feelings, emotions, and emotional states - good nature, geniality (kindness of heart), amiability, amenity and cosiness. This emotional range is fixed in modern definitions of the lexemes Gemütlichkeit and gemütlich (see, e.g., gemütlich - '1) cosy, native (close); 2) relaxed, cheerful, intimate; 3) friendly, amicable, hearty and a bit simple-minded' (DKW, 1997, p. 391)).

Not only psychologists but also linguists, sociologists, and culture experts paid attention to the fact that a complex emotional state of a peculiar cosiness is familiar first of all to the representatives of North European language ethnic groups (Norsemen), as it is here that the words denoting the given state exist (see, e.g., Lomas, 2016; Smith, 2015), e.g., Dan.' hygge, Norv. hygge, kos, koselig, Finn. kodikas, Swed. mysig, gemytlig. Even those Anglo-Saxons who were exposed to harsh and cold weather conditions as a result of migration, in particular Canadians, have a notion of this kind - HOMINESS (Linnet, 2011, p. 35; Wiking, 2016, pp. 32-34) or HOMEYNESS (McCracken, 1989, p. 174).

The languages mentioned above, except Finnish, are related since they belong to the same language group Germanic. That is why these languages have close in form and meaning cross-lingual equivalents, e.g., Engl. cosy $\rightarrow$ Norv. kos, koselig; Dan. hygge $\rightarrow$ Norv. hygge; Germ. gemütlich $\rightarrow$ Swed. gemytlig; Germ. Gemütlichkeit $\rightarrow$ Dutch gemoedelijkheid. However, some formal counterparts greatly differ in their content, e.g., Swed. hygge, unlike Dan. hygge, has a meaning 'cutting down, forest clearing, forest opening' (Glosbe, 2020).

It is worth noting that despite the fact that Dutch has a noun gemoedelijkheid formally similar to the German lexeme Gemütlichkeit, researchers consider another noun - gezelligheit - to be closer in content to this lexeme (Levisen, 2012; Smith, 2015). The noun gezelligheit names an ethnospecific notion embracing both physical and inner cosiness, i.e., (a) peace of mind in the company of friends / family members in a warm and homely ambience (the presence of friends and family members is obligatory) and (b) emotional state of safety, cosiness, and comfort (Smith, 2015). The Danish lexeme hygge is also equivalent to Gemütlichkeit for which reason some scholars regard Germ. Gemütlichkeit, Dutch gezelligheit and Dan. hygge as cross-lingual equivalents (Levisen, 2012; Linnet, 2011). However, unlike the Dutch GEZELLIGHEIT and Danish HYGGE, the German concept GEMÜTLICHKEIT, characterizing the state of the peace of mind, demonstrates a greater degree of connection with the inner world of an individual (Schmidt-Lauber, 2003).

\footnotetext{
${ }^{1}$ Hereafter: Danish - Dan., Norwegian - Norv., Finnish - Finn., Swedish - Swed., English - Engl., Ukrainian - Ukr., Russian - Rus.
} 
The afore mentioned makes it possible to assume that common and different features in the semantics of the lexemes Germ. Gemütlichkeit, Dutch gezelligheit, gemoedelijkheid, Dan. hygge, Norv. hygge, kos, koselig, Finn. kodikas, Swed. mysig, gemytlig, Engl. cosiness, hominess (homeyness) are conditioned not only by interlingual (common / different etymology, degree of languages relatedness), but also by cross-cultural factors (common / different ethno- and sociocultural conditions of a definite language ethnos development). The latter are to a great extent influenced by weather conditions and geographic location of this or that linguistic community. In view of this, one can assume that a need for a cosy, warm, emotionally comfortable atmosphere arises first of all in the places where darkness (a short day or no daylight at all), long and cold winter, severe frost and so on prevail. Cold climate makes people stay inside for a long period of time, stimulating them to create as cosy atmosphere as possible. In these conditions warm, cosy, and comfortable atmosphere together with amiable communication with friends and family members becomes of great importance. As a matter of fact, these moments are reflected in the semantics of the corresponding lexemes of North Germanic languages, as well as in Dutch gezelligheit, gemoedelijkheid and Engl. hominess (homeyness).

Opposite to the afore mentioned, a milder climate, warmer and sunnier weather result in people's suffering from autumn-winter depression to a smaller degree. Consequently, their feeling of loneliness and acute need for communication with other people diminish. It is possible to assume that just because of that the semantics of friendly communication is of a smaller importance for the lexemes Germ. Gemütlichkeit and Engl. cosiness. This logical assumption enables to explain the fact that in South European language cultures there are no concepts similar to GEMÜTLICHKEIT. The Italian concept DOLCE FAR NIENTE and French SAVOIR VIVRE are rather close but what is implied here is the ability to enjoy life and feel comfortable. Such French words and word combinations as comfortable, agréable, il fait bon ici or oú l'on se sent á l'aise do not fully render the semantics of Gemütlichkeit either (Krüger-Lorenzen, 1972).

It is noteworthy that in Slavic language cultures, in particular in Russian and Ukrainian, the concept analogous to the German GEMÜTLICHKEIT, is also missing ${ }^{2}$. And it is regardless of the fact that on the territories where these ethne live, especially in the north of Russia, the climate is really harsh. Moreover, a Ukr. word затишність, затишок and Russ. уют, which can be viewed as cross-lingual equivalents of the noun Gemütlichkeit, render only part of its semantics: Ukr. затишність - '1) protection from wind; stream flow etc.; 2) calm; mild display of smth; carelessness; 3) convenience; orderliness; pleasure of being somewhere; amenities; 4) inconspicuous, hidden'; затишок - '1) quiet place; protected from wind, stream flow etc.; 2) inconspicuous, hidden place; hiding place; 3) absence of sounds, noises, movement, fuss; silence; 4) calm, orderliness, convenience of some place; 5) peace of mind; quiet solace' (DUL, 1972, vol. 3, pp. 350, 351); Russ. yют - 'convenient order; well-equipped household, surroundings' (Ozhegov and Shvedova, 1997, p. 814). Close in content to the lexeme Gemütlichkeit is a Ukrainian noun затишок, which reflects the semantics of the peace of mind and quiet solace (family (home) comfort; inward peace etc.). However, even the presence of this semantics gives no grounds for viewing the lexemes Gemütlichkeit and затишок as equivalent.

As opposed to the Russians and Ukrainians for whom the concepts Ukr. ЗАТИШНІСТЬ / ЗАТИШОК, Rus. УЮТ mean first of all inward peace connected with the family home, the Germans understand GEMÜTLICHKEIT as a stable pleasant state of mind. Representatives of the German language culture use the words Gemütlichkeit / gemütlich to refer to an evening or a room, pleasant walk, they describe gloomy weather as ungemütlich [uncosy]. They snuggle to have a rest from a stressful working day or feel cosy communicating with close friends (Chesnokova, 2013). Because of that the concept GEMÜTLICHKEIT is closely connected with the ethnospecific concept FEIERABEND, which has no one-word designation in other languages; therefore, it is rendered as a rule with the help of the following word combinations - the end of the working day, holiday eve or off-work evening time.

A person's need for a warm and cosy atmosphere during outer weather unpleasantness is quite natural. That is why typical of GEMÜTLICHKEIT is not only the evening time but also late autumn and winter, when it is cold

\footnotetext{
${ }^{2}$ Cf., here also: Czech pohodli 'comfort; comfortable; convenient; convenience; solace, cosiness'; útulnost 'cosiness; comfort (in a dwelling); Slovak pohodli 'comfort; convenience; cosiness'; útulnost' "cosiness; comfort'; Polish komfort 'comfort; solace, convenience; reassurance; cosiness; wygoda 'comfort; solace; convenience; cosiness'; przytulność 'cosiness'; zacisze 'seclusion; cosiness' (Glosbe, 2020).
} 
and unpleasant outside, and it is good to sit inside wrapped in a warm blanket, with a cup of hot tea or coffee (Chesnokova, 2013). However, there are some grounds to claim that the concept GEMÜTLICHKEIT appeared and developed in German-speaking language cultures not so much under the influence of weather conditions as due to certain sociohistorical and sociocultural processes. For example, ethnologist B. Schmidt-Lauber (2003) observes that since the end of the $18^{\text {th }} \mathrm{c}$. the concept GEMÜT [nature; character; soul] has acquired the status of the features of German national character, being used for the opposition of the Germans and their "eternal enemies" - the French who were regarded as frivolous and superficial. As a result, from the middle of the $19^{\text {th }}$ century, the concept GEMÜTLICHKEIT derived from GEMÜT was actualized in the German-speaking community since the former supplemented the latter, underlining the specificity and complexity of the German national character.

Beginning from that particular time the relevance of the concept GEMÜTLICHKEIT was increasing and decreasing depending on the historical events (e.g.: World Wars I and II, annexation / loss of German-speaking territories) and sociocultural changes. Fig. 1 clearly demonstrates synchronous oscillations of the concepts GEMÜT, GEMÜTLICHKEIT and GEMÜTLICH in different historical periods. The second half of the XX $\mathrm{c}$. is an exception as unlike GEMÜTLICHKEIT and GEMÜTLICH, beginning with 1945 until today there has been a gradual deactualization of the concept GEMÜT in German-speaking communities.

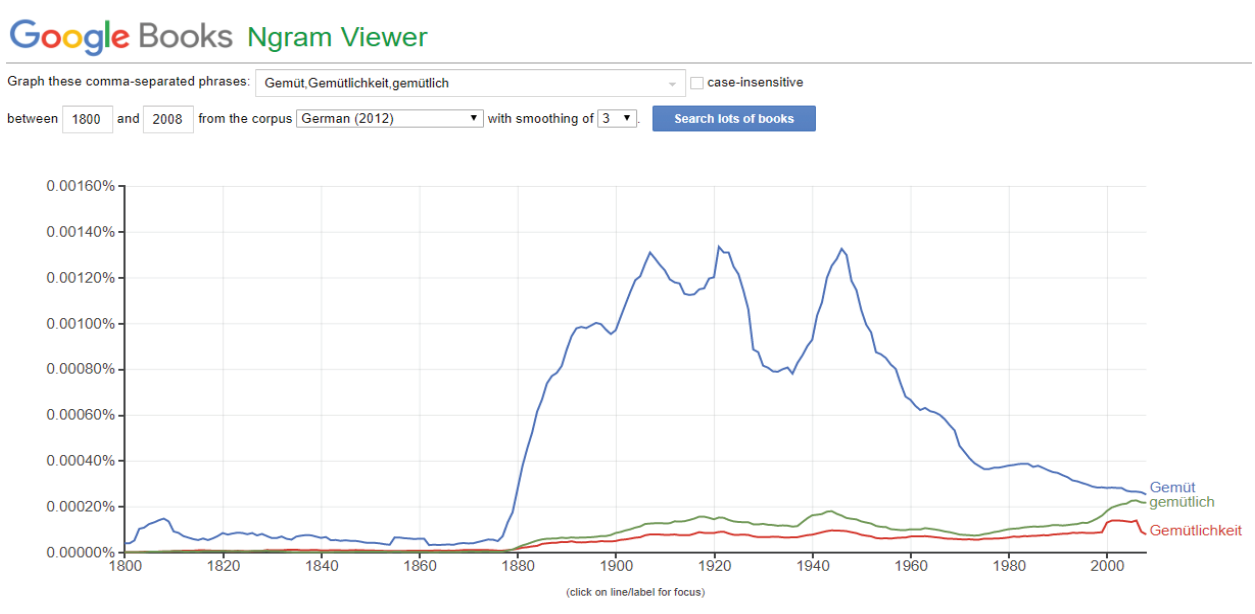

Fig. 1 Diagram of frequency of lemmata Gemüt, Gemütlichkeit, gemütlich according to Google Books Ngram Viewer; the German language; 1800-2008; smoothing 3 (GBNV, 2020)

The diagram shows that the following periods are absolutely synchronous: (a) beginning of the analysed notions actualization during the Biedermeier epoch (petty-bourgeois romanticism), (b) upward trend during the period of wide spreading of national or nationalist ideas (German-speaking lands unification in the second half of the $19^{\text {th }}$ c., economic growth before the beginning of World Wars I and II, "economic miracle" (Wirtschaftswunder) after World War II, (c) downturn after the aforementioned wars (deactualization of national / nationalist ideas). One can also clearly trace the actualization of the concepts GEMÜTLICHKEIT and GEMÜTLICH during the period of West and East Germany reunification (1990) together with the deactualization of the concept GEMÜT and the present day deactualization of all the three concepts as a result of total globalization and digitalization that have caused some break of traditions and a gradual loss of "the national spirit".

Polarization of the German-speaking ethne's "spirit", especially of the Germans, on the axis Chaos [chaos] - Ordnung [order] (see, e.g., Nuss, 1993, pp. 195-196; Wierzbicka, 1999, pp. 159-166) promoted the formation of the whole set of interdependent ethnospecific notions. So, for example, chaos, together with causing existential fear (Angst), actualized in the minds of the representatives of the German-speaking cultural community a permanent disposition toward the order: the less order, the greater the fear (see Fig. 2). Relevance peak of the concept ORDNUNG in the $20^{\text {th }}$ century coincides with the beginning of World War II, i.e., the period of the apex of the 
"national spirit", economic growth and the belief in the future of German-speaking communities. The defeat in the war ruined the established order of things in these communities; therefore, from this time onward the sociocultural importance of the order begins to diminish, instead the importance of the existential fear starts to grow practically on a pro rata basis, which clearly demonstrates the interdependence of these notions.

Existential fear, in its turn, highlights such concepts as SICHERHEIT [safety, certainty], GEBORGENHEIT [shelteredness] and ZUVERLÄSSIGKEIT [reliability]. GEMÜTLICHKEIT is closely and deeply related to these concepts (Bausinger, 2005). It is connected with the fact that the senses of chaos and fear create the discrepancy between the inner world harmony of an average representative of German-speaking ethne and disharmony of the outer world, where different historical and sociocultural factors cause the fear of the future that suppresses "the spirit". In order to get rid of this suppression, one has to immerse in the atmosphere of GEMÜTLICHKEIT.

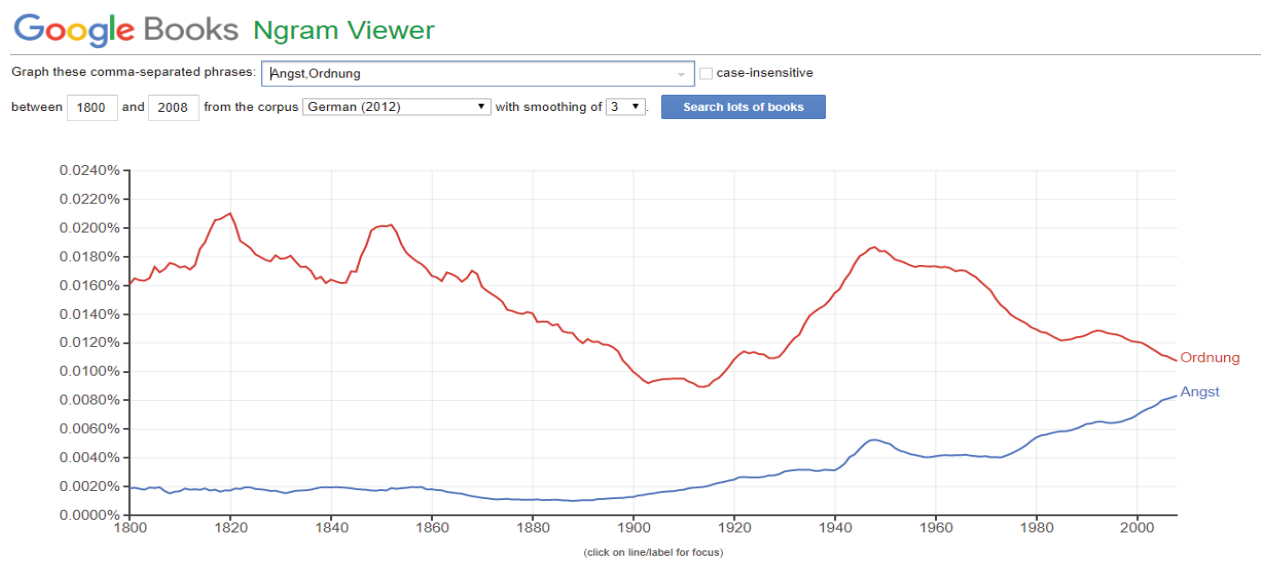

Fig. 2 Diagram of frequency of lemmata Angst, Ordnung according to Google Books Ngram Viewer; the German language; 1800-2008; smoothing 3 (GBNV, 2020)

Fig. 3 (see p. 51) clearly demonstrates a consistently high sociocultural importance of the concept SICHERHEIT in the analysed linguocultures during the last centuries. As opposed to it, the need for the protection appeared only after the defeat of Germany in World War II. It is noteworthy that the concept ZUVERLÄSSIGKEIT the importance of which has been growing lately is more relevant than the concept GEBORGENHEIT. It can be explained by the fact that ZUVERLÄSSIGKEIT possesses the whole range of senses connected with reliability. In this case, reliability implies not so much a feature of a person or a functional reliability of some device, machinery and different technical structures but rather refers to stability of a world order within the German cultural space, since the concept ZUVERLÄSSIGKEIT is associated with safety, confidence in the future, trust in established order of things or familiar (reliable) people, responsible attitude to one's duties, thoroughness (tendency towards perfectionism), trueness (of faith, convictions, values) etc.

One can assume that this particular "safety-cosiness quartet" of value system of the German-speaking communities - SICHERHEIT, ZUVERLÄSSIGKEIT, GEBORGENHEIT and GEMÜTLICHKEIT - forms that fragment in their world picture which together with ORDNUNG is opposed to the existential insecurity (fear), i.e., to the concept ANGST (Fig. 4). It completely agrees with the observations of G. Hofstede (2006) that in Germany UNSICHERHEITSVERMEIDUNG as a criterion of cultures contrast plays a pivotal role. Typical features of the representatives of the cultures with a high level of uncertainty avoidance, in particular of the Germans, are observation of the norms of behaviour and the laws, negative attitude to ambiguity, careful long-term planning of the future, need for clear and detailed written instructions, openness in criticism, indisposition for risk appetite. It is worth noting that the peace of mind and comfort that constitute an essential part in the content of the concept GEMÜTLICHKEIT as well as of UNSICHERHEITSVERMEIDUNG. 
Interpretation of the concept GEMÜTLICHKEIT based on corpus data

The analysis of the LCC-concordance of the word query Gemütlichkeit revealed such relevant senses of the analysed concept:

Google Books Ngram Viewer

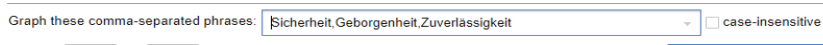

between 1800 and 2008 from the corpus German (2012) V with smoothing of 3 . S Search lots of books

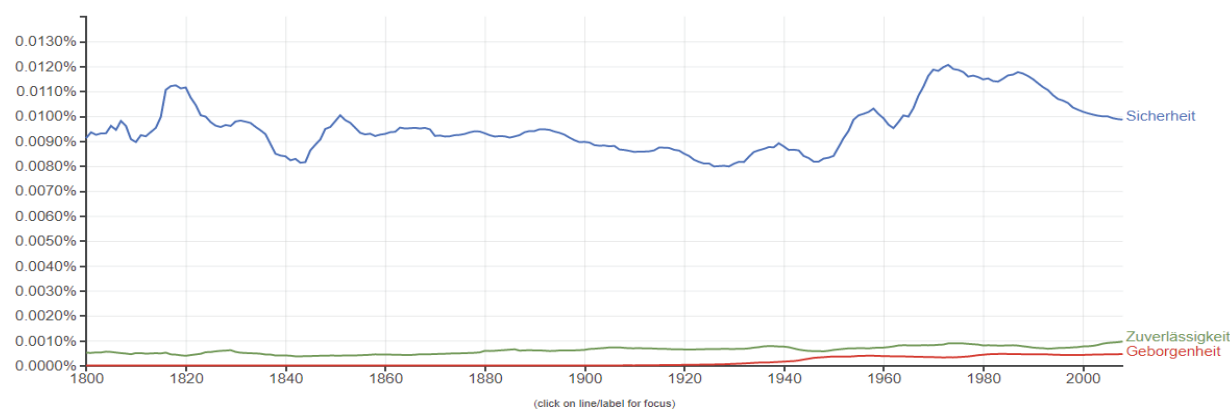

Fig. 3 Diagram of frequency of lemmata Sicherheit, Geborgenheit, Zuverlässigkeit according to Google Books Ngram Viewer; the German language; 1800-2008; smoothing 3 (GBNV, 2020)
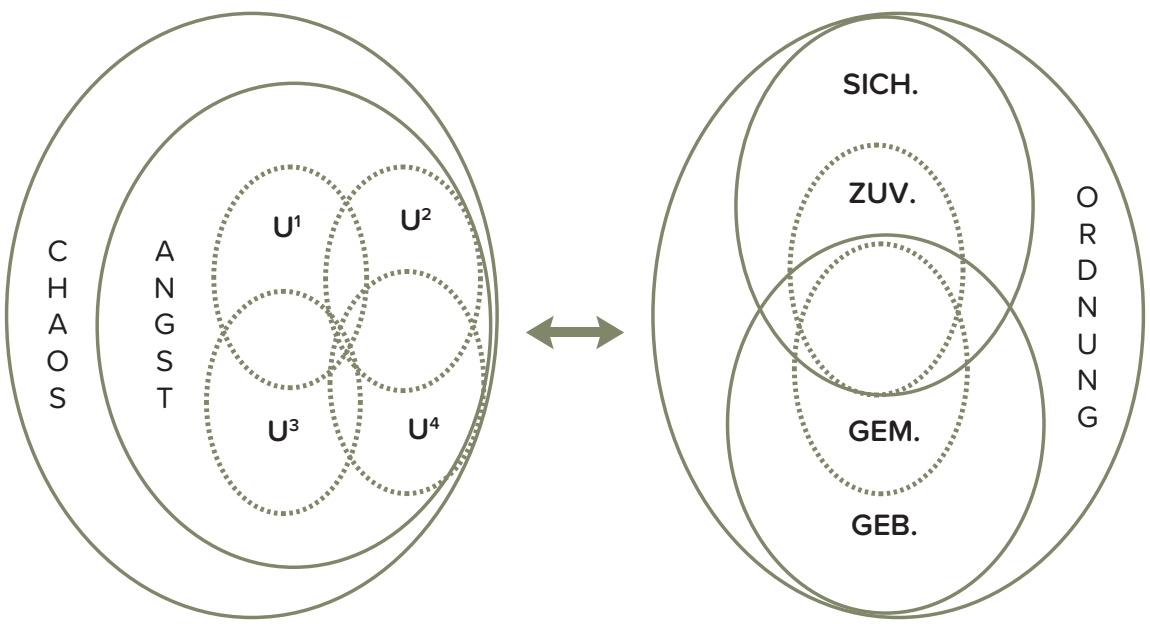

Fig. 4 Scheme of contrasting German ethnospecific "safety-cosiness" concepts to the concept ANGST (U' - UNZUVERLÄSSIGKEIT, U² - UNSICHERHEIT, U³ - UNGEMÜTLICHKEIT, U4 - UNGEBORGENHEIT, SICH. - SICHERHEIT, GEB. - GEBORGENHEIT, ZUV. - ZUVERLÄSSIGKEIT, GEM. - GEMÜTLICHKEIT)

1 'comfort', e.g., Das ist ein heller, schmaler Raum, der mit Sofas und Lounge-Liegen urbane Gemütlichkeit ausstrahlt [This is a cheerful, narrow room which radiates urban cosiness by its sofas and arm-chairs];

2 'peace of mind', e.g., Als ich das gläserne Dampfbad im Wellness-Bereich dann doch finde, bin ich erleichtert über die Gemütlichkeit [When I do find a steam sauna in a spa salon I feel better because of the feeling of cosiness]; 
3 'social comfort', e.g., Gemütlichkeit bedeutet für mich, niemanden sehen zu müssen [For me "Gemütlichkeit" means absence of necessity to see somebody];

4 'amity / friendliness', e.g., Hauptgrund seien soziale Aspekte wie Geselligkeit und Gemütlichkeit - sowohl in Familien als auch beim Spieleabend mit Freunden [The main reasons are such social factors as friendliness and cosiness - both in the family circle and while playing with friends in the evening];

5 'physical and mental relaxation', e.g., Gemütlichkeit: Endlich wieder Sofa-Zeit! [Cosiness: sofa-time again at last!];

6 'mental cosiness', e.g., Drinnen verbreiten warme Farben mit viel Holz eine konservative Gemütlichkeit [Inside warm colours together with rich wood decoration create conservative (traditional) cosiness];

7 'mental solace', e.g., Als ich mich auf diese Geschichte vorbereitete, lag ich an einem See in Brandenburg und wollte in aller Gemütlichkeit die Einführung in die Gender Studies von Franziska Schößler lesen [When I was preparing for this event I was lying on a lakeshore in Brandenburg and wanted to read the introduction to gender studies by Franziska Schößler in the atmosphere of utmost cosiness].

These senses prove that in the minds of German-speaking ethne GEMÜTLICHKEIT can be (a) an emotion, (b) an emotional state, (c) a feeling, and (d) a social phenomenon. In the latter case GEMÜTLICHKEIT functions as a feature of the national character of the Germans, Austrians, and Swiss, e.g.,

8 Kurz entschlossen stürzte ich mich in das, was rund um den Erdball als deutsche "Gemütlichkeit" gerühmt wird [Without hesitation I plunged headlong into the thing that is famous all over the world as the German "cosiness", the so called "Gemütlichkeit"];

9 Hier muss die schweizerische Gemütlichkeit mit asiatischer Eleganz zusammenfinden [Here the Swiss cosiness, the so called "Gemütlichkeit", should be combined with the Oriental elegance].

This feature is clearly counterpoised to the similar but "alien" notions, e.g.,

10 Es sind noch knapp zweihundert Kilometer bis zur Grenze, hinter der hygge wieder "Gemütlichkeit" heißt und man dabei an Eichenschrankwände denkt, an Kupferteller, den röhrenden Hirsch an der Wand und den Tatort mit Jan Josef Liefers [Some 200 kilometres to the border after which hygge (Danish cosiness) will be again called "Gemütlichkeit" (German cosiness) and one will think about an oak wall unit, about a copper plate, a belling deer on the wall and about a series "Crime Scene" with Jan Josef Liefers].

It is noteworthy that GEMÜTLICHKEIT can be even ascribed to some region within German-speaking ethne, e.g.:

11 Da schwätzten angesehene Leute [...] von der westdeutschen "Gemütlichkeit" [Here respectable people were gossiping [...] about the West German "cosiness", the so called "Gemütlichkeit"].

According to the LLC-corpus, Bavarian but not German cosiness is particularly frequent (cf. tokens bayerische (273), bayerischer (202), urbayerische (131) as left collocates of the lemma Gemütlichkeit). As a social phenomenon GEMÜTLICHKEIT demonstrates not only positive but also negative shades, because such cosiness can provoke indifference to social problems (philistine cosiness). In this sense it can be depressing and delusional, as well as unnatural, non-existent, faked or stimulated by some pragmatic aim, e.g.:

12 Sie ironisieren die kleinbürgerlichen Geschmacksideale und die beklemmende und trügerische Gemütlichkeit der 1960er Jahre [They mock at petty bourgeois ideals of taste and at depressing and delusional "cosiness", the so called "Gemütlichkeit", of the 60-s of the previous 
century];

13 Doch obwohl es jeden Grund gab, vor dieser turbopragmatischen Gemütlichkeit mit ihrem Nützlichkeitswahn davonzulaufen [...] blieb ich und kam immer wieder [Despite the solid grounds for escaping from this extremely pragmatic cosiness, the so called "Gemütlichkeit", with its mania of practicality, [...] I stayed on and kept coming again and again].

Nevertheless, in spite of the fact that the concept GEMÜTLICHKEIT can cause negative associations (narrow-minded, philistine, stupid cosiness etc.), it is also the object of nostalgia (one can miss it), e.g.:

14 Ich habe mich nach dieser dämlichen bayerischen Gemütlichkeit gesehnt [I missed that stupid Bavarian cosiness, the so called "Gemütlichkeit"].

Negative aspect of GEMÜTLICHKEIT - is solely sociocultural estimation of this notion. However, as a complex emotional state (emotion, feeling) this cosiness is joyful being a symbiosis of positive emotions and feelings, e.g.:

15 Wenn alle den Menschen so viel Freude und Gemütlichkeit bereiten würden wie Karel Gott, dann wäre die Welt wirklich ein schöner Ort [If everybody gave people as much joy and peace of mind, the so called "Gemütlichkeit", as Karel Gott, then our world would be much better].

Like joy GEMÜTLICHKEIT can be radiated, e.g.:

16 Das runde Gesicht des werdenden Familienvaters strahlt Gemütlichkeit aus [A round face of the would-be father radiates cosiness, the so called "Gemütlichkeit"].

It is the emotional nature of GEMÜTLICHKEIT that conditions its connection in the "naive" consciousness with liquid, which can fill a person from within (as everybody knows it is considered to be a common feature of emotions), e.g.:

17 Ich habe Gemütlichkeit getankt, bevor ich nach Reykjavík aufbreche [I refuelled with cosiness, the so called Gemütlichkeit, before leaving for Reykjavík].

The analysis of the LCC-concordance fragments showed that a cognitive metaphor GEMÜTLICHKEIT IS LIQUID is rather relevant for the German-speaking ethne (502 examples out of 12886 fragments - 3.9\%), e.g.:

18 Der Ort verströmt eine Ruhe und Gemütlichkeit, die in den überfüllten Skigebieten der Alpen längst verloren gegangen ist [The place overflowed with tranquillity and peculiar cosiness, the so called "Gemütlichkeit", which had been long lost in the overcrowded ski areas in the Alps].

It is worth noting that emotions and feelings can be associated with a certain independent force or a phantom creature that comes into contact with people and often confronts them. GEMÜTLICHKEIT, as an imaginary force / creature can crawl out, come, attack etc., e.g.:

19 Das Aan de Amstel ist ein Lokal, in dem die hochwertige Gemütlichkeit aus allen Fugen kriecht ["Aan de Amstel" - is a café where unsurpassed cosiness, the so called "Gemütlichkeit", crawls out from every crack].

A key factor for a person to experience the emotional state of GEMÜTLICHKEIT is the creation of the appropriate emotional atmosphere. It is first of all the feeling of unalloyed peace of mind as cosiness can not appear in the atmosphere of stress, haste and pressure. That is why negative external influence, events causing external stress destroy GEMÜTLICHKEIT. This state needs the feeling of comfort, absence of physical and psychological suffering, hunger or thirst, sadness or fear. It is because of this that GEMÜTLICHKEIT is contrasted to difficult and unpleasant things. Representatives of the German-speaking ethne perceive it as the opposite of their work activity, attributing revitalizing powers to it (Schmidt-Lauber, 2003).

The creation of the atmosphere necessary for GEMÜTLICHKEIT and of the appropriate mood depend on the presence of "the national spirit" embodied in traditional artefacts where every object reminds of one's own home and local colour (Christmas celebrations, various carnivals, beer festivals etc.). In Germany, for example, 
all these things can be described by one concept - TYPISCH DEUTSCH [typically German] (for more details see Schroll-Machl, 2003, p. 18), which is rooted in the stereotypes about German culture and German national character, e.g.:

20 Hier dagegen genießt man die Ruhe anthrazitfarbener, mit Steinchen verputzter Wände und die Gemütlichkeit großer Holztische, die bei gutem Wetter auch draußen stehen [Instead here one enjoys the tranquillity of the walls painted in anthracite colour and covered with stones and cosiness, the so called Gemütlichkeit", of big wooden tables which in good weather are also put outside].

The fire burning in the mantelpiece on a cold evening is sometimes sufficient "to get immersed" in the emotional state of GEMÜTLICHKEIT as open fire creates the centre of the life space around which the whole family comes together especially in winter, and a red-yellow flame light, crackle of firewood, fragrance of the burning wood lend a particular cosy atmosphere to the dwelling (Chesnokova, 2013), e.g.:

21 Seit diesem Monat ist es an Tagen, an denen Feinstaub-Alarm herrscht, dort verboten, nur für die Gemütlichkeit den Kamin anzufeuern [Beginning this month on those days when the warning sign about fine dust dominates, it is forbidden to light a fireplace just for cosiness, the so called "Gemütlichkeit"].

Conversely, the absence of all these things makes the creation of the atmosphere of GEMÜTLICHKEIT impossible. Moreover, not everybody can experience this state because of anxiety or inability to relax, e.g.:

22 Spartanische Bänke und Hocker strahlen Konzentration aus, keine Gemütlichkeit [Austere benches and stools radiated concentration rather than cosiness, the so called "Gemütlichkeit"];

23 Ich besitze nämlich kein Talent zur Gemütlichkeit [I have no gift for creating peculiar cosiness, the so called "Gemütlichkeit"].

The senses of conventionality, traditional character, "national spirit" counterpoise the concept GEMÜTLICHKEIT to existential fear. The feeling of permanent insecurity provokes an irresistible inclination, in particular for the Germans, to create the atmosphere of confidence, based on the knowledge of what might happen as well as on the need for certain clear outlines of the near future, e.g.:

24 Sein unerschütterlicher katholischer Glaube, seine Biederkeit und die Gemütlichkeit seines Privatlebens vermittelten den Menschen ein Gefühl von Beständigkeit in einer unsicher gewordenen Welt [His steadfast Catholic faith, his decency and cosy surroundings, the so called "Gemütlichkeit", of his private life gave people the feeling of stability in the world that became insecure].

Taking this into account the atmosphere GEMÜTLICHKEIT is a kind of a cocoon in which a person feels not only comfortable but also experiences a peace of mind and high spirits (joy) due to the warmth radiated by familiar things as well as nearest and dearest people nice to talk to. Talking is not essential though, it is sufficient to watch the world around in a pleasant state of mind, as GEMÜTLICHKEIT - is at the same time something intimate, unique for every person.

\section{Semantic profile of the lexeme Gemütlichkeit}

The conducted analysis made it possible to reveal the influence of sociocultural and sociohistorical factors on the formation of the concept GEMÜTLICHKEIT in the German-speaking cultural space against the background of several other languages and cultures. For that purpose, the etymology of the lexeme that is the name of the notion has been defined, its semantic content has been specified on the basis of dictionary definitions, its relevant senses have been revealed with the help of the LCC-data. However, for the representative of a non-German speaking community to gain a more or less adequate idea of the emotional state GEMÜTLICHKEIT, it is necessary do define the minimal but at the same time representational range of the notions which represent that particular state. One 
of the research procedures that can in a scientifically objective way help solve the problem is the creation of a semantic profile of the word query Gemütlichkeit.

For working out this semantic profile, it is necessary to define the most frequent autosemantic tokens that are co-occurrent similar forms, co-occurrents and left and right collocates of the word query Gemütlichkeit (data according to LCC, 2020):

a co-occurrent similar forms: gemütliche (0.12) [cosy], Atmosphäre (0.11) [atmosphere], Wärme (0.10) [warmth];

b co-occurrents: Prosit (761) [toast], Komfortkamine (281) [comfort fireplace], Hygge (260) [hygge], Wärme (234) [warmth], Geselligkeit (232) [conviviality], sorgen (218) / sorgt (119) [take care / takes care], volkstümlicher (202) [folky], Harmonikastadl (184), strahlt (184) / strahlen (106) [radiates / radiate], Todtenweis (166), Waldhäuser (156), Ruhe (153) [rest], bayerische (146) / bayerischer (146) [Bavarian], Kamin (134) [fireplace], Dschungelbuch (133) [Jungle Book], Stimmung (121) [mood], Wohnzimmer (112) [living room] , im Zeichen (109) / Zeichen (74) [under the sign of / sign], dienen (108) [serve], urige (106) [traditional, cosy], Wänden (95) / Wände (73) [walls], Ambiente (95) [ambience], Landhausstil (95) [country house style], Essen (94) [food], Charme (92) [charm], Zuhause (90) [home], Remstalhalle (88), Entschleunigung (85) [deceleration], Trumpf (82) [trump], Licht (79) [light], Holz (78) [wood], Hektik (78) [rush / hecticness], Gastfreundschaft (76) [hospitality], Betriebsverbot (76) [non-operation rule], Entspannung (74) [relaxation], Komfort (74) [comfort], Gäste (69) [guests];

c left collocates: bayerische (273) / bayerischer (202) [Bavarian] / urbayerische (131) [typical Bavarian] / bayerischen (30) / Bayerische (27) [Bavarian], urige (125) / uriger (50) [traditional, cosy], viel (124) [many / much], aller (96) [all], strahlen (82) [radiate], heimelige (59) [homely], wohlige (57) [pleasant, cosy], rustikale (56) [rustic], österreichische (55) [Austrian], fränkische (49) [Frankish], Wiener (48) [wiener], steirische (48) [Styrian], verströmen (42) [radiate], Schützenverein (40) / Schützenvereins (31) [gun club], Theaterverein (40) [theatre club], deutsche (32) / deutscher (23) [German], entspannte (31) [relaxed], winterlichen (31) [winterly], dänischen (25) [Danish], verbreiten (23) [spread];

d right collocates: dienen (228) [serve], Todtenweis (216), Hollenbach (88), Mertingen (84), Weilbach (81), sorgen (77) / sorgt (39) [take care of / takes care of], ausstrahlt (67) / ausstrahlen (63) [radiates / radiate], Olching (42), steht (41) [stays], strahlen (30) [radiate], vermitteln (28) [convey], verleiht (26) [lends], geht (25) [goes], genieBen (24) [enjoy], kommt (24) [comes], schätzen (20) [appreciate].

It is noteworthy that the most frequent co-occurrent similar forms and co-occurrents are predominantly nominative tokens that denote the notions creating the atmosphere of GEMÜTLICHKEIT or are associated with this emotional state (e.g.: warmth, toast, fireplace, amiability, traditional life, tranquillity, good mood, food, light, rest, comfort). The most frequent left collocates are, as a rule, adjectival tokens naming regional varieties of the concept GEMÜTLICHKEIT (e.g., Bavarian, Austrian, Frankish, Wiener, German cosiness) or characterizing it (traditional, homely, rustic, wintry cosiness). The most frequent right collocates are verbal tokens (e.g., to go, radiate, convey, enjoy, appreciate). However nominative tokens are also abundant (e.g., Todtenweis, Hollenbach, Mertingen). The latter name cities and towns (predominantly Bavarian) which are famous for their traditions, festivals, carnivals, holidays etc., that create the atmosphere of a particular cosiness.

A number of the most frequent tokens represent both syntagmatic and paradigmatic distribution of the semantic profile of the word query Gemütlichkeit, which makes it possible to single out four "peaks" of the profile (see Fig. 5).

On the basis of Fig. 5, it is possible to formulate a relevant definition of the lexeme Gemütlichkeit, since at present neither authoritative dictionaries nor reference books nor electronic sources give a definite and at the same time complete definition of the latter. This definition is important first of all to the representatives of the non-German speaking communities as it might help them to get a more or less complete idea of the analysed emotional state. It is often difficult for them to comprehend this fragment in the emotional world of the Germans, Austrians and Swiss. Thus, the word Gemütlichkeit denotes an ethnospecific emotional state of cosiness, which is the emotional reaction of the representatives of the German-speaking cultural space to the inner and outer 
discomfort; this state appears only in a cosy atmosphere where a person - alone or in a company of close people - enjoys the emotional warmth and spiritual comfort. It is noteworthy that in this definition one can trace no connection of the concept GEMÜTLICHKEIT with the middle class, which is stated by some contemporary researchers (see, e.g., Cole, 2011).

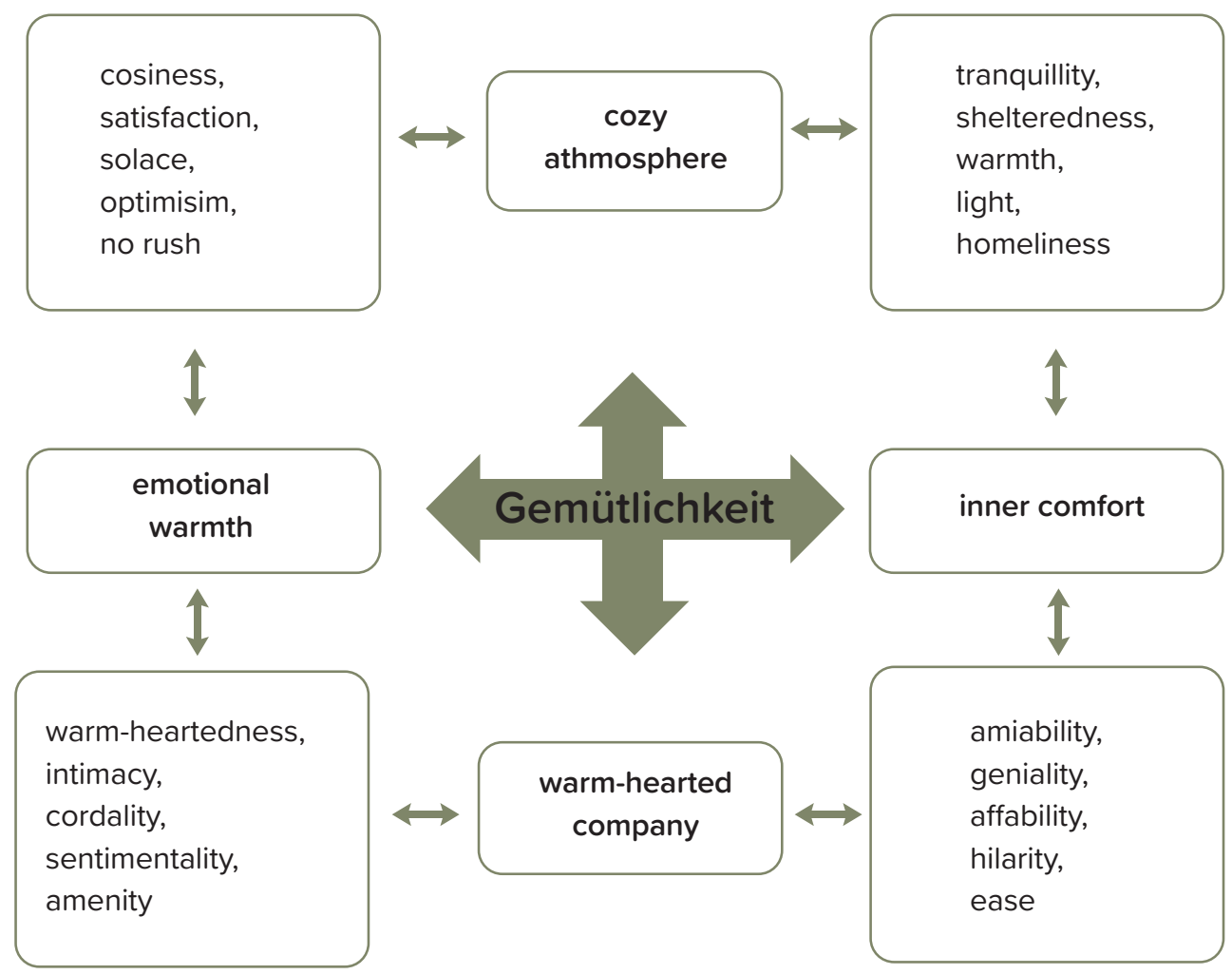

Fig. 5 The four "peaks" of the word query Gemütlichkeit

\section{Conclusions}

The cross-cultural study of the German emotion concept GEMÜTLICHKEIT intended:

1 to reveal linguo-specificity of its name (lexeme Gemütlichkeit) on the basis of etymological, definitional and contextual analysis;

2 to establish this lexeme's lexical equivalence, i.e., its partial counterparts in the English, Danish, Dutch, Swedish, Norwegian, Finnish, Ukrainian, Russian and other languages;

3 to use the cross-cultural data as well as the data of the representational language corpora.

Supplementation of the results of the etymological and definitional study of the lexeme Gemütlichkeit with the cross-cultural analysis enabled to define those sociohistorical and sociocultural factors which contributed to the transformation of the concept GEMÜTLICHKEIT into the whole fragment of the emotional world of the Germans, Austrians and Swiss. It was found that together with the concepts SICHERHEIT, ZUVERLÄSSIGKEIT and GEBORGENHEIT the concept GEMÜTLICHKEIT forms a unique "safety-cosiness" quartet of the representatives of German-speaking communities' value system, i.e., the fragment of their world picture, which together with the concept ORDNUNG is opposed to the existential fear - ANGST.

The analysis of concordance fragments with the word query Gemütlichkeit made it possible to reveal the senses of this word, which form the relevant image of the concept GEMÜTLICHKEIT in the minds of the rep- 
resentatives of the German-speaking cultural space: 'comfort', 'spiritual comfort', 'social comfort', 'affability', 'amiability', 'physical and spiritual rest', 'inner cosiness', 'spiritual solace'. The "peaks" of the semantic profile of the analysed word query - 'cosy atmosphere', 'inner comfort', 'emotional warmth' and 'warm-hearted company' - are at the same time basic features of the concept GEMÜTLICHKEIT. These features form the basis for the relevant definition of the lexeme Gemütlichkeit. The development of the definition was aimed not only at closing the gap in reference literature that needs a clear and complete definition of the notion "Gemütlichkeit", but also at forming an adequate idea of this emotional state in the minds of the representatives of non-German-speaking communities.

The results of the data analysis suggest further linguistic insights into cross-cultural study of specific emotional concepts by means of the approbated corpus-based methodology, which will allow establishing sematic profile of language units nominating such concepts. These emotion-specific findings can reveal a rich number of semantic facets of emotional concepts relevant to other language communities.

\section{References}

1 Bausinger, H. (2005). Typisch deutsch. Wie deutsch sind die Deutschen? München: C. H. Beck Verlag.

2 Briggs, J. L. (1970). Never in Anger: Portrait of an Eskimo Family. Cambridge: Harvard University Press.

3 Bruza, P. D., Barros, A. P., \& Kaiser, M. (2009). Augmenting Web Service Discovery by Cognitive Semantics and Abduction. In Proceedings of Web Intelligence and Intelligent Agent Technologies, 2009. WI-IAT '09. IEEE/WIC/ACM International Joint Conferences, 15-18 September 2009. Milan: University of Milano-Bicocca, (pp. 71-82).

4 Chesnokova, L. (2013). Gemütlichkeit (uyut) kak odin iz klyuchevykh kontseptov nemetskoy kul'tury [Gemütlichkeit as One of Key Concepts of the German Culture]. In Filosofiya $i$ kul'tura [Philosophy and Culture], (8), (pp. 1121-1130). (In Russian). https://doi. org/10.7256/1999-2793.2013.8.6957.

5 Cole, J. E. (2011). Ethnic Groups of Europa: An Encyclopaedia. Santa Barbara, CA/Denver, CO/Oxford, Eng.: ABC-CLIO.

6 Dewaele, J. M. (2015). Culture and emotional language. In Sharifian, F. (Ed.), The Routledge Handbook of Language and Culture. London, New York: Routledge, (pp. 357-370).

7 Döcker, U. (1994). Die Ordnung der bürgerlichen Welt. Verhaltensideale und soziale Praktiken im 19. Jahrhundert. Frankfurt am Main, New York: Campus.

8 Elfenbein, H. A., \& Ambady, N. (2002). On the Universality and Cultural Specificity of Emotion Recognition: A Meta-analy- sis. In Psychological Bulletin, 128(2), (pp. 203-235). https://doi.org/10.1037/00332909.128.2.203

9 Fransella, F. (1995). George Kelly (Key Figures in Counselling and Psychotherapy series). London et al.: SAGE Publications Ltd.

10 Friedlmeier, W., Corapci, F., \& Cole, P. M. (2011). Socialization of Emotions in Cross-cultural Perspective. In Social and Personality Psychology Compass, 5(7), (pp. 410-427). https://doi.org/10.1111/j.17519004.2011.00362.x.

11 Hofstede, G. (2006). Lokales Denken, globales Handeln. Interkulturelle Zusammenarbeit und globales Management. München: C.H. Beck Verlag.

12 Jenkins, R. (2014). At Vare Dansk: Identitet $i$ hverdagslivet. København. Museum Tusculanums Forlag.

13 Kamandulytè-Merfeldienè, L., \& Balčiūnienè, I. (2016). Syntactically Coded Corpus of Spoken Lithuanian: Developmental Issues and Pilot Studies. In Kalbu studijos / Studies about Languages, 28, 92-101. http://dx.doi. org/10.5755/j01.sal.0.28.15131.

14 Kövecses, Z. (1990). Emotion Concepts. New York: Springer.

15 Krüger-Lorenzen, K. (1972). Deutsche Redensarten - und was dahintersteckt. Wiesbaden: VMA-Verlag.

16 Levisen, C. (2012). Cultural Semantics and Social Cognition: A Case Study on the Danish Universe of Meaning. Berlin, Boston: Walter de Gruyter GmbH.

17 Linnet, J. T. (2011). Money Can't Buy Me 
Hygge: Danish Middle-class Consumption, Egalitarianism and the Sanctity of Inner Space. In Social Analysis: Journal of Cultural and Social Practice, 55(2), 21-44.

18 Lomas, T. (2016). Towards a Positive Cross-cultural Lexicography: Enriching Our Emotional Landscape through 216 "Untranslatable" Words Pertaining to Well-being. In The Journal of Positive Psychology, 11(5), 546-558. http://dx.doi.org/10.1080/174 39760.2015 .1127993$.

19 McCracken, G. (1989). Homeyness: A Cultural Account of One Constellation of Consumer Goods and Meanings. In Hirschman, E. C. (Ed.), Interpretive Consumer Research (pp. 168-183). Provo, UT: Association for Consumer Research.

20 McEnery, T., \& Wilson, A. (2001). Corpus Linguistics. Edinburgh: Edinburgh University Press.

21 Medvedeva, T. S., Oparin, M. V., \& Medvedeva, D. I. (2011). Klyuchevyie kontseptyi nemetskoy lingvokulturyi [Key Concepts of the German Linguo-culture]. Izhevsk: Udmurt University Press. (In Russian).

22 Mizin, K., \& Korostenski, J. (2019). "Western" Cultural Linguistics and "Post-Soviet" Linguoculturology: Causes of Parallel Development. In Linguistychni Studiyi [Linguistics studies], 37, 7-13. http://dx.doi. org/10.31558/1815-3070.2019.37.1.

23 Mizin, K., \& Letiucha, L. (2019). The Linguo-cultural Concept TORSCHLUSSPANIK as the Representative of Ethno-specific Psycho-emotional State of Germans. In Psycholinguistics, 25(2), 234-249.

24 Mizin, K., Letiucha, L., \& Petrov, O. (2019). Deutsche linguokulturelle Konzepte im Lichte der germanisch-ostslawischen Kontraste: Methode zur Feststellung von spezifischen bzw. einzigartigen Bedeutungen. In Germanos/avica, 30(1), 49-70.

25 Mizin, K., \& Ovsiienko, L. (2020). The German Linguo-cultural Concept SCHADENFREUDE in Cross-cultural Perspective: A Corpus-based Approach. In Lege artis. Language yesterday, today, tomorrow. The journal of University of SS Cyril and Methodius in Trnava, 5(1), 143-184.

26 Nuss, B. (1993). Das Faust-Syndrom. Ein
Versuch über die Mentalität der Deutschen. Bonn, Berlin: Bouvier Verlag.

27 Oster, U. (2012). "Angst" and "Fear" in Contrast: A Corpus-based Analysis of Emotion Concepts. In Brdar, M., Raffaelli, I. and Žic Fuchs, M. (Eds.), Cognitive Linguistics between Universality and Variation (pp. 327355). Newcastle upon Tyne: Cambridge Scholars Publishing.

28 Panasenko, N. (2012). Linguistic Markers of Emotional Concept LOVE in Literary Texts. In US-China foreign language, no 10 (4), (pp. 1067-1084).

29 Popova, Z. D., Sternin, I. A., Karasik, V. I., Kretov, A. A., Boriskina, O. O., Pimenov, E. A., \& Pimenova, M. V. (2009). Vvedenie $v$ kognitivnuyu lingvistiku [An Introduction to Cognitive Linguistics]. Kemerovo: Kemerovo University Press. (In Russian).

30 Reddy, W. (2012). The Making of Romantic Love: Longing and Sexuality in Europe, South Asia, and Japan, 900-1200 CE. Chicago, IL: University of Chicago Press. doi: 10.1002/jhbs.21640.

31 Robinson, C. J., \& Altarriba, J. (2015). Culture and Language Processing. In Sharifian, F. (Ed.), The Routledge Handbook of Language and Culture (pp. 240-252). New York, NY: Routledge. https://doi. org/10.4324/9781315793993.

32 Röttger-Rössler, B., \& Markowitsch, H. J. (Eds.), (2009). Emotions as Bio-cultural Processes. New York: Springer.

33 Schmidt-Lauber, B. (2003). Gemütlichkeit: eine kulturwissenschaftliche Annäherung. Frankfurt am Main: Campus Verlag.

34 Schmidt-Lauber, B. (2004). Europäische Ethnologie und Gemütlichkeit. Fragen einer Alltagskulturwissenschaft. In Österreichische Zeitschrift für Geschichtswissenschaften, 15(4), 27-49.

35 Schroll-Machl, S. (2003). Die Deutschen Wir Deutsche. Fremdwahrnehmung und Selbstsicht im Berufsleben. Göttingen: Vandenhoeck and Ruprecht.

36 Stefanowitsch, A. (2005). The function of metaphor: Developing a corpus-based perspective. International Journal of Corpus Linguistics, 10(2), 161-198. https://doi. org/10.1075/ijcl.10.2.03ste. 


\section{Dictionaries
and Sources \\ Dictionaries
and Sources}

$1 \mathrm{DH}$ (Duden Herkunftswörterbuch. Der Duden in zwölf Bänden). (Vol. 7). (2001). Mannheim: Bibliographisches Institut.

2 DKW (Der kleine Wahrig. Wörterbuch der deutschen Sprache). (1997). Gütersloh: Bertelsmann Lexikon Verlag $\mathrm{GmbH}$.

3 Duden. (2020). [viewed 19 April 2020]. Retrieved from: https://www.duden.de/rechtschreibung/Gemuetlichkeit.

4 DUL (Dictionary of the Ukrainian Language) (Vol. 3). (1972). Kyiv: Naukova Dumka Press. (In Ukrainian).

5 GBNV (Google Books Ngram Viewer). (2020). [viewed 17 February 2020]. Retrieved
41 Wilson, P. A., \& Lewandowska-Tomaszczyk, B. (2017). Pride in British English and Polish: A Cultural Linguistics Perspective. In Sharifian, F. (Ed.), Advances in Cultural Linguistics (pp. 373-409). Singapore: Springer. https:// doi.org/10.1007/978-981-10-4056-6_12.

42 Winawer, H., \& Wetzel, N. A. (2005). German Families. In McGoldrick, M., Giordano, J., \& Garcia-Preto, N. (Eds.), Ethnicity and Family Therapy (pp. 555-570). New York, London: The Guildford Press.

43 Zaliznyak, A. A., Levontina, I. B., \& Shmelev, A. D. (2005). Klyuchevyie idei russkoy yazykovoy kartinyi mira [Key Ideas of the Russian Language Picture of the World]. Moscow: Languages of Slavis Culture. (In Russian).

from: https://books.google.com/ngrams.

6 Glosbe. (2020). [viewed 23 February 2020]. Retrieved from: https://uk.glosbe.com/.

7 LCC (Leipzig Corpora Collection: Deutsches Nachrichten-Korpus basierend auf Texten gecrawlt 2018). (2020). [viewed 29 January 2020]. Retrieved from: http://corpora. uni-leipzig.de/.

8 Lexico. (2020). [viewed 9 January 2020]. Retrieved from: https://www.lexico.com/?search_filter=dictionary.

9 Ozhegov, S. I., \& Shvedova, N. Yu., (1997). Thesaurus of the Russian language. Moscow: Azbukovnik. (In Russian).

\section{Santrauka}

\section{Kostiantyn Mizin, Oleksandr Petrov. GEMÜTLICHKEIT emocinè būsena tarpkultūriniame kontekste: tekstynu gristas tyrimas}

Straipsnis skirtas tarpkultūriniam GEMÜTLICHKEIT sąvokos tyrimui, kuris atspindi etnospecifinę emocinę būseną, aktualią vokiškai kalbančioms visuomenèms. Šiuo tikslu etimologinès, apibrèžties ir kontekstinès analizès, atitikmenų paieškos, tarpkultūrinių duomenų ir reprezentacinių tekstynų duomenų analizè atskleidžia šios sąvokos pavadinimo, t. y. leksemos Gemütlichkeit, kalbini specifiškumą. Nustatyta, kad GEMÜTLICHKEIT sąvoka kartu su SICHERHEIT, ZUVERLÄSSIGKEIT ir GEBORGENHEIT sąvokomis sudaro unikalų „saugų ir jaukų“ vokiškai kalbančios visuomenès vertybinės sistemos kvartetą, t. y. jų pasaulèžiūros fragmentą, kuris kartu su ORDNUNG sąvoka priešinasi egzistencinei baimei - ANGST. Tekstyno duomenų pagrindu buvo sukurtas užklausos žodžio Gemütlichkeit semantinis profilis. Šio profilio viršūnèse yra pagrindiniai GEMÜTLICHKEIT sąvokos požymiai, kurie sudaro pagrindą aktualiam leksemos Gemütlichkeit apibrèžimui. Formuluojant ši apibrezžimą buvo siekiama ne tik užpildyti žinynų ir kitų informacijos šaltinių, kuriuose reikia aiškiai ir išsamiai apibrèžti GEMÜTLICHKEIT sąvoką, spragą, bet ir sukurti tinkamą šios emocinès būsenos apibrèžti, suvokiamą vokiškai nekalbantiems žmonèms. 
About the Authors

\section{KOSTIANTYN MIZIN}

Doctor of Philology, Professor, Head of the Department of Foreign Philology, Translation and Teaching Methodology, Pereiaslav-Khmelnytskyi Hryhorii

Skovoroda State Pedagogical University, Ukraine

Research interests

Contrastive linguistics, contrastive linguoculturology, phraseology, cognitive linguistics, translation studies.

\section{Address}

Suchomlyns'koho St., 30, 08400,

Pereiaslav, Ukraine

E-mail

kmizin@i.ua

Scopus Author ID: 57195981991

ORCID: 0000-0002-5216-6032

\section{OLEKSANDR PETROV}

CSc, Assistant Professor at Department of Germanic and Slavic Philology and World Literature, Vinnytsia Mykhailo Kotsiubinsky State Pedagogical University, Ukraine

\section{Research interests}

Contrastive linguistics, contrastive linguoculturology, phraseology, cognitive linguistics, translation studies.

\section{Address}

Ostroz'kyj St., 32, 21100, Vinnytsia, Ukraine

E-mail

alexpetroff35@gmail.com

Scopus Author ID: 57195979384

ORCID: 0000-0003-4641-3559 